\title{
SILICON IN FOODS: CONTENT AND BIOAVAILABILITY
}

\author{
Harry Robberecht ${ }^{1,2}$, Kristien Van Dyck ${ }^{1}$, Douwina Bosscher ${ }^{1}$, \\ and Rudy Van Cauwenbergh ${ }^{1}$ \\ ${ }^{1}$ University of Antwerp (UA), Department of Pharmaceutical Sciences, \\ Laboratory of Nutrition and Functional Food Science, Antwerp, Belgium \\ ${ }^{2}$ Plantijnhogeschool, Antwerp, Belgium
}

The silicon content of various foodstuffs marketed in Belgium was measured by a validated graphite furnace absorption spectrometric method. Dietary intake has been identified as the major source of silicon. However, data on its bioavailability remain scarce and insufficient. In vitro methods can provide an indication of bioavailability in case of lacking in vivo data. Bioavailability of silicon from different foodstuffs was estimated using an in vitro continuous flow gastroduodenal simulation method. The major food sources of silicon were unrefined grains, cereal products and root vegetables. The availabilities of silicon from, meat, milk and beers were high, whereas low availability was observed for seafood and cereal products. Plotting the availability data versus the total elemental silicon content of the foods revealed an exponential inverse relationship. The inverse relationship between silicon content and silicon availability was found in all foods, with the exception of various silicon containing drinks. Nevertheless, food categories classified as major silicon sources in the diet still appear to provide the highest absolute amounts of available silicon per $100 \mathrm{~g}$ of food including breakfast cereals, bread and baking products, and beers.

Keywords: Silicon, Concentration level, Foodstuffs, Availability.

\section{INTRODUCTION}

It is evident that silicon plays an important role in human physiology. Besides its important role in bone mineralization and soft tissue development, silicon is nowadays claimed to have beneficial effects on several human disorders. Examples are its role in prevention of osteoporosis, ageing of skin, hair and nails and atherosclerosis. ${ }^{[1-6]}$ Several reports about the silicon content of foods have been published. ${ }^{[7-11]}$ Data on the daily intake of silicon from 24-h duplicated meals, measured by validated graphite furnace atomic absorption have been published previously by our group. ${ }^{[12]}$ However, besides intake level, the bioavailability of the element is of paramount importance in normal physiology. As recently pointed out, data on the bioavailability of silicon are scarce and need to be established. ${ }^{[13,14]}$ Exploring the bioavailability of silicon from foods in humans is impaired by several factors such as natural abundant and the lack of detailed information on Si-metabolism in human.

Received 28 June 2006; accepted 19 July 2007.

Address correspondence to Harry Robberecht, University of Antwerp (UA), Department of Pharmaceutical Sciences, Laboratory of Nutrition and Functional Food Science, Universiteitsplein 1, Antwerp B-2610, Belgium. E-mail: labrom@ua.ac.be 
A dynamic continuous flow dialysis can be used as an alternative in vitro technique to study bioavailability of minerals and trace elements in meals, ${ }^{[15,16]}$ infant formulae and milks. ${ }^{[17-20]}$ It is an in vitro simulation of the digestion of food. The strength of this model, since it does not provide absolute bioavailability data, is its ability to demonstrate relative differences in availability comparing different foodstuffs. Besides, it proved to be very useful in predicting changes in availability after addition of various food ingredients. ${ }^{[15]}$ The aim of this paper is to contribute to the knowledge on the bioavailability of silicon from various food items in a standarized and well-defined in vitro experiment.

\section{MATERIAL AND METHODS}

\section{Foods Used}

Various foodstuffs were collected at different places in the Antwerp and Brussels region (Belgium) at the beginning of September 1997.

\section{Silicon Determination}

A Perkin Elmer model 4100 ZL Zeeman atomic absorption spectrometer (AAS), equipped with a PE AS-70 autosampler, was used for all experiments. The manufacturer's recommendations for wavelength, spectral width and lamp current parameters were followed. The adapted programme, matrix modification and the analytical features for silicon determination were published earlier. ${ }^{[12]}$ All procedures (lyophilisation, destruction, and elemental analysis) were carried out in duplicate. Sample preparation and microwave oven destruction with optimized heating programme was carried out as described elsewhere. ${ }^{[12]}$

To check accuracy of the AAS-technique, an interlaboratory trial on spectrometric determination of silicon in certain food items and biological samples was performed, because of the lack of certified reference material. ${ }^{[21,22]}$ Mean Si-value $( \pm$ SD) from water was $16.4 \pm 1.0 \mathrm{mg} / \mathrm{L}(\mathrm{pj}=13$, number of participating laboratories $)$, from spinach after destruction $3.32 \pm 0.15 \mathrm{mg} / \mathrm{L}(\mathrm{pj}=10)$ and from beer after destruction $8.65 \pm 0.47 \mathrm{mg} / \mathrm{L}$ $(\mathrm{Pj}=10)$. Precision of the procedure was checked by analyzing ten replicates of diluted destruction liquids and mean Si-values $( \pm \mathrm{SD})$, were $28.2 \pm 1.0 \mathrm{mg} / \mathrm{kg}$ flour, $4.51 \pm 0.23$ $\mathrm{mg} / \mathrm{kg}$ spinach and $1.64 \pm 0.05 \mathrm{mg} / \mathrm{kg}$ yoghurt (fresh weight). Characteristic mass yielded $\mathrm{Si}$-values of $47 \mathrm{pg} / 0.0044 \mathrm{~A}-\mathrm{s}$ and detection limit in the destruction liquid was $31.8 \mu \mathrm{g} / \mathrm{l}$.

\section{Bioavailability Studies}

Detailed description of the optimized procedure of the continuous flow dialysis model can be found elsewhere. ${ }^{[23]}$ The continuous flow in vitro dialysis model consisted of two phases: a gastric and a duodenal stage. Prior to the gastric stage, 10-50 g of the food was brought to $\mathrm{pH} 2.0$ with $6 \mathrm{~N} \mathrm{HCl}$. Pepsin was added and the sample was placed two hours at $37^{\circ} \mathrm{C}$ in a shaking water bath $(120$ strokes $/ \mathrm{min})$. The intestinal phase was mimicked in a stirred cell under a pressure of 3.5 bars at $37^{\circ} \mathrm{C}$.

Continuous removal of dialyzed compounds was obtained through a dialysis membrane with molecular weight cut off of $1000 \mathrm{Da}$. During the first $30 \mathrm{~min}$ of dialysis the $\mathrm{pH}$ of the digest was gradually increased from acid to neutral by use of a dialysis bag (MWCO $10-12 \mathrm{kDa}$ ) filled with $1 \mathrm{M} \mathrm{NaHCO}_{3}$. After 30 min of dialysis, pancreatin-bile extract was 
added to the neutralized sample and dialysis was continued for another two hours. The availability of the element was directly calculated from the amount of element that passed the dialysis membrane in proportion to the total elemental content of the food sample, following the equation:

$$
\% \text { availability }=\mathrm{D} / \mathrm{W} \times \mathrm{A} \times 100 \%,
$$

where D is the total amount $(\mu \mathrm{g})$ of dialysed silicon; W is the dry weight $(\mathrm{g})$ of food sample; and A the concentration of silicon in the food sample $(\mu \mathrm{g} / \mathrm{g})$.

According to their silicon concentration and water content, 10 to $50 \mathrm{~g}$ of foodstuff were taken through the procedure. Four replicate samples were used for each item and 10 replicates for calculation of the precision. Recovery and precision of the procedure on 0.5 , 2.5 , and $75.0 \mathrm{mg} \mathrm{Si} / 100 \mathrm{ml}$ standard solutions yielded mean values of 107,101 , and $102 \%$, respectively, and $0.336 \pm 0.04,1.76 \pm 0.12$, and $58.8 \pm 1.4 \mathrm{mg} \mathrm{Si} / 100 \mathrm{ml}$, respectively.

\section{RESULTS}

Silicon content. Table 1 summarizes the silicon content and the bioavailability for various food items. High silicon values were observed in breakfast cereals and vegetables, while low values were found in meat and dairy products. Fish also showed low values,

Table 1 Availability data for silicon in various foodstuffs (mean \pm SD).

\begin{tabular}{|c|c|c|}
\hline Food item & $\begin{array}{l}\text { Total Si content } \\
\text { ( } \mu \mathrm{g} / 100 \mathrm{~g} \text { food; } \\
\text { wet weight })\end{array}$ & Availability (\%) \\
\hline \multicolumn{3}{|l|}{ Meat } \\
\hline Beef (minced) & 121 & $72 \pm 15$ \\
\hline Chicken (breast) & 109 & $40 \pm 4$ \\
\hline \multicolumn{3}{|l|}{ Seafood } \\
\hline Mussels & 9588 & $5.5 \pm 0.6$ \\
\hline Scampi & 1000 & $11.1 \pm 0.8$ \\
\hline \multicolumn{3}{|l|}{ Cereals } \\
\hline Breakfast & 8250 & $7.7 \pm 2.5$ \\
\hline Oat flakes & 18,800 & $2.1 \pm 0.4$ \\
\hline Rice (whole) & 16,200 & $7.6 \pm 1.3$ \\
\hline Whole wheat flour & 2770 & $20.0 \pm 0.5$ \\
\hline \multicolumn{3}{|l|}{ Milk and formulae } \\
\hline Cow's milk & 76 & $49 \pm 8$ \\
\hline Soy milk & 580 & 72 \\
\hline Milk for toddlers & 124 & $62 \pm 1$ \\
\hline Infant formulae (brand 1) & 2080 & $64 \pm 5$ \\
\hline (brand 2) & 1275 & $55 \pm 7$ \\
\hline \multicolumn{3}{|l|}{ Vegetables and fruit } \\
\hline Beans & 5577 & $0.6 \pm 0.1$ \\
\hline Leek & 63 & $75 \pm 11$ \\
\hline Spinach & 1782 & $4.9 \pm 0.3$ \\
\hline Bananas (mixed) & 6195 & $5.8 \pm 0.7$ \\
\hline \multicolumn{3}{|l|}{ Drinks } \\
\hline Beer (tin can) & 1980 & $109 \pm 0.8$ \\
\hline Tea (infusion of leaves) & 18,100 & $20 \pm 2$ \\
\hline
\end{tabular}


with the exception of mussels, which appeared to be silicon rich $(8.4 \pm 0.8 \mathrm{mg} / 100 \mathrm{~g})$ Within the fruit group, the silicon content of dried fruit and bananas was remarkably high. Particularly high levels were obtained for instant coffee, tea and soup. Unrefined grains tend to be higher in silicon concentration than refined products, like rice, bread and cereals.

Silicon level in mineral waters reveal a wide range from 0.076 to nearly $2 \mathrm{mg} / 100 \mathrm{ml}$. Daily water consumption in Belgium is about $1.5 \mathrm{~L} /$ person, consequently water can contribute in a large extent to the daily silicon intake. $80 \%$ of the tested beers show silicon levels of about $2 \mathrm{mg} / 100 \mathrm{ml}$ and higher, therefore beer can be considered as a medium source of the element.

Availability. Plotting the availability data versus the total silicon content reveals an exponential inverse relationship $\left(y=68.85 \times^{-0.4923}, \mathrm{R}^{2}=0.442\right)$ (Figure 1). Food items previously found to contain high silicon levels showed very low availability: beans $(0.6 \%)$, oat flakes $(2.1 \%)$ and mussels $(5.5 \%) .{ }^{[10,16,18]}$ Nearly all food items from both categories milk and meat revealed availabilities between 40 and $70 \%$. Tea leaves and wheat flour displayed intermediate silicon availabilities. Beers, waters, and milks proved to contain highly available silicon.

Because of this relationship-i.e., low silicon availability and concomitant high silicon content - the variation (range) in the amount of available silicon (absolute; $\mu \mathrm{g}$ ) between food items is relatively small. With respect to the differences in the concentration levels between the different food items, a range of almost 1000 is observed, whereas this range is reduced to almost 100 at the availability levels (absolute; $\mu \mathrm{g}$ ). Food categories, previously classified as silicon rich, still appear to provide the highest amounts of available silicon per $100 \mathrm{~g}$ of food. These include, from high to low, breakfast cereals, bread and baking products, and beer ordered from high to low. Infant formula proved to be an important source of silicon for infants because of their high silicon content and a considerable availability.

\section{DISCUSSION}

Analysis of the various individual foodstuffs in Belgium reveals that cereals and grains contain more silicon than meat products. Especially breakfast cereals, rice and bread and baking products appear to have high silicon content. Meat and dairy products

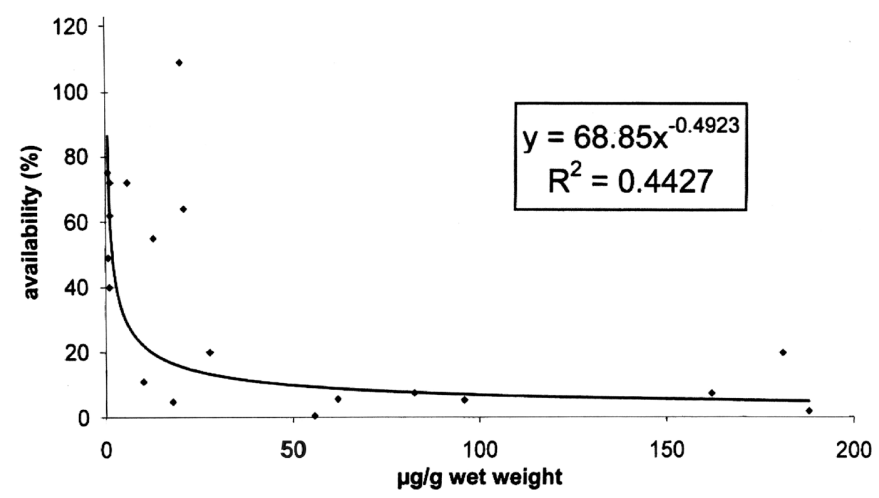

Figure 1 Silicon availability from various foodstuffs as a function of silicon content. 
proved to be particularly poor in silicon, while vegetables, fruit and fish displayed a rather heterogeneous pattern. These observations correlate well with published data. ${ }^{[13]}$

In our study silicon content was determined in a variety of foodstuffs commercially marketed in Belgium to identify foods that are silicon sources in the Western diet. Vegetarian foodstuffs contained varying amounts of silicon. ${ }^{[10]}$ High levels were found in rice products, a fungus-based meat substitute (Quorn $\left.{ }^{\circledR}\right)$ and in roasted barley containing mostly more than $2 \mathrm{mg} \mathrm{Si} / 100 \mathrm{~g}$ wet weight. People adhering to a vegetarian diet, therefore, consume more silicon than people consuming normal non-vegetarian meals. ${ }^{[10]}$ The high silicon content of fish, especially shellfish, may be explained by the enormous water filtration capacity of these organisms. The addition of amorphous silicon dioxide as anticaking agent to instant food may be responsible for the high silicon levels found in instant tea.

In this study, availability of silicon from various foodstuffs was determined by an in vitro continuous flow dialysis method as an estimate of the bioavailability of the element. Bioavailability can be described as that portion of a nutrient that can be used. This means that any potentially available part of a nutrient after gastrointestinal digestion should be attributed to its availability. However, measuring the release and solublization of micronutrients in vitro does not necessarily represent the efficiency with which they will be translocated by the intestinal mucosa and used for metabolic functions. Both measurements are also partly dependent on physiologic factors. Therefore, in vitro methods are particularly usefull to predict the release of micronutrients from meals and to identify underlying food portions that affect bioavailability without considering host-releated influences.

The availability data on silicon from various foodstuffs demonstrated high values for those food items, which appeared to have low total silicon content, along with low availability for those with high elemental content (Table 1). Taking into account the mean silicon concentration of food categories and food consumption patterns in Belgium, it appears that as few as seven food groups supply more than $80 \%$ of the daily dietary intake of the element. ${ }^{[12]}$

The high availability of silicon from beers was in agreement with observations of Bellia et al. ${ }^{[24]}$ They calculated that $42-75 \%$ (mean $56 \%$ ) of silicon in beer was excreted in urine within $8 \mathrm{~h}$ after ingestion. During fabrication of beers with hot mashing techniques orthosilicic acid may be extracted from the phytolytic silica, a hydrated polymer $\mathrm{SiO}_{2} \cdot \mathrm{nH}_{2} \mathrm{O}$, present in barley. Reffitt et al. ${ }^{[25]}$ also suggested that orthosilicic acid is readily absorbed from the gastrointestinal tract of man and subsequently excreted in urine. Mean uptake of silicon from an ingested orthosilicic acid (27-55 mg Si/l) in water was $50.3 \%$ (range $22-75 \%$ ) based on urinary analysis following dosing.

Availability of silicon from daily meals taken on subsequent days is about $30 \%$ with rather small day-to-day variation. Meals were collected by 24 -h duplicate portions and availability determined by the in vitro methodology. This value is somewhat lower than the overall mean of $40.9 \pm 36.3 \%$ in the Framingham study. ${ }^{[13]}$ In the latter study, availability data were calculated from urinary silicon excretion over a 6-h period after ingestion of various food groups. The observations in the Framingham cohorts on bananas were confirmed in our study. Not only the silicon content was very similar, but also little silicon was available from the edible portion. ${ }^{[13]}$

Much of the silicon present in cereals is phytolytic silica with poor bioavailability. ${ }^{[24]}$ This was also proven by Kelsay et al. ${ }^{[26]}$ Silicon intake on a high fiber diet is almost twice the amount compared with intakes on a low fiber diet. Urinary excretions of silicon were $58 \%$ and $35 \%$ of the intake on the low and high fiber diets. Mean silicon balance was negative in both diets but significantly more negative for the high fiber diet $(\mathrm{p}<0.01)$. 
Although most food categories with high silicon content show relative low availability, when calculated as absolute available amounts $(\mu \mathrm{g})$ these food categories still provide major amounts of silicon from the daily diet.

The relatively high availability of Si from milk and infant formulae is an interesting feature in view of the probable essential character of this element for bone growth. ${ }^{[27-29]}$ As a result of high consumption of vegetables-based food, ${ }^{[30-32]}$ Asians ${ }^{[33]}$ and Indians ${ }^{[34]}$ have a much higher silicon intake than a Western population: $19 \mathrm{mg} /$ day for Belgium (12), $31 \mathrm{mg} /$ day for the UK (12) and $30 \mathrm{mg}$ and $33 \mathrm{mg} / \mathrm{d}$ in the original Framingham and Framingham offspring cohorts, respectively. ${ }^{[13]}$ In the latter study higher intake was proven for men compared to women and silicon intake increased as a function of age. ${ }^{[13]}$ Blood silicon levels in China did not significantly differ from values found in Belgium as proven in a small study, on a limited number of persons. ${ }^{[3]}$ This may support the hypothesis that most of the silicon from rich food items may be not available, since daily silicon intakes are much higher in China (139 mg/day) compared to Belgium (19 mg/day). The higher silicon intake was not reflected in serum concentration levels in humans.

\section{CONCLUSION}

Due the inverse relationship-i.e., low silicon availability and concomitant high silicon content—conditions of silicon deficiency and excess have not been demonstrated in humans. Correspondingly, clinical signs of silicon deficiency responsive to supplemental dietary intake, obligatory for proving essentiality, could not be identified for this element. ${ }^{[33-35]}$ On the other hand, homeostatic regulation of serum silicon levels, ${ }^{[3]}$ with respect to pregnant women, may prove supporting evidence for the essential character of this element. More extensive longitudinal studies have to be carried out to enforce these promising observations.

\section{ACKNOWLEDGMENTS}

H. Robberecht thanks the University of Antwerp (UA) for use of research facilities on a freelance basis. The Plantijn Hogeschool (Antwerp) accepted his additional scientific activity through the Antwerp Association for schools of higher education and the University of Antwerp. D. B. was financially supported by an IWT grant.

\section{REFERENCES}

1. King, E.J.; Belt, T.H. The physiological and pathological aspects of silica. Physiological Reviews 1938, 18, 329-365.

2. Carlisle, E.M.; Silicon. In : O’Dell, B.L.; Sunde, R.A., Eds. Handbook of nutritionally essential mineral elements. New York : Marcel Dekker, Inc, 1997, 18, 603-618.

3. Van Dyck, K; Robberecht, H.; Van Cauwenbergh, R; Van Vlaslaer, V.; Deelstra, H. Indication of silicon essentiality in humans. Serum concentrations in Belgian children and adults, including pregnant women. Biological Trace Element Research 2000, 77, 25-32.

4. Rico, H.; Gallego-Lago, J.L.; Hernandez, E.R.; Villa, L.F.; Sanchez-Atrio, A.; Sero, C.; Gervas, J.J. Effect of silicon supplement on osteopenia induced by ovariectomy in rats. Calcified Tissue International 2000, 66, 53-55.

5. Reffitt, D.M.; Ogston, N.; Jugdaohsingh, R.; Cheung, H.F.J.; Evans, B.A.J.; Thompson, R.P.H.; Powell, J.J.; Hampson, G.N. Orthosilicic acid stimulates collagen type 1 synthesis and osteoblastic differentiation in human osteoblast-like cells in vitro. Bone 2003, 32, 127-135. 
6. Jugdaohsingh, R.; Tucker, K.L.; Qiao, N.; Cupples, L.A.; Kiel, D.P.; Powell, J.J. Dietary silicon intake is positively associated with bone mineral density in men and premenopausal women of the Framingham Offspring Cohort. Journal of Bone and Mineral Research 2004, 19, 297-307.

7. Bowen, H.J.M.; Peggs, A. Determination of silicon content of food. Journal of Science of Food and Agriculture 1984, 35,1225-1229.

8. Varo, P.; Koivistoinen, P. Mineral element composition of Finnish foods. XII. General discussion and nutritional evaluation. Acta Agriculturae Scandinavia 1990, Suppl 22, 165-171.

9. Pennington, J.A. Silicon in foods and diets. Food Additives and Contaminants 1991, 8, 97-118.

10. Robberecht, H.; Hendrix, P.; Van Cauwenbergh, R.; Van Dyck, K.; Deelstra, H. Mineral and trace element content of various vegetarian foodstuffs available in Belgium. Zeitschrift für Lebensmittel-Untersuchung und -Forschung A 1999, 208, 156-161.

11. Robberecht, H.; Van Dyck, K.; Van Cauwenbergh, R.; Deelstra, H. Dietary silicon intake in Belgium : sources, availability from foods, and support of the importance for humans. Intern. J. Food Properties 2008 (in press).

12. Van Dyck, K.; Robberecht, H.; Van Cauwenbergh, R.; Deelstra, H. Daily dietary silicon intake in Belgium, using duplicate portion sampling. European Food Research and Technology 1999, $210,77-79$.

13. Jugdaohsingh, R.; Anderson, S.H.C.; Tucker, K.L.; Elliott, H.; Kiel, D.P.; Thompson, R.P.H.; Powell, J.J. Dietary silicon intake and absorption. American Journal of Clinical Nutrition 2002, 75, 887-893.

14. Sripanyakorn, S.; Jugdaohsing, R.; Elliott, H.; Walker, C.; Mehta, P.; Shoukru, S.; Thompson, R.P.A.; Powell, J.J. The silicon content of beer and its bioavailability in healthy volunteers. British Journal of Nutrition 2004, 91, 403-409.

15. Van Dyck, K.; Tas, S.; Robberecht, H.; Deelstra, H. The influence of different food components on the in vitro availability of iron, zinc and calcium from a composed meal. International Journal of Food Sciences and Nutrition 1996, 47, 499-506.

16. Bosscher, D.; Van Cauwenbergh, R.; Van der Auwera, J.-C.; Robberecht, H.; Deelstra, H. Calcium, iron and zinc availability from weaning meals. Acta Paediatrica 2002, 91, 1-8.

17. Bosscher, D.; Van Caillie-Bertrand, M.; Van Dyck, K.; Robberecht, H.; Van Cauwenbergh, R.; Deelstra, $\mathrm{H}$. Thickening infant formula with digestible and indigestible carbohydrate : availability of calcium, iron, and zinc in vitro. Journal of Pediatric Gastroenterology and Nutrition 2000, 30, 373-378.

18. Bosscher, D.; Van Caillie-Bertrand, M.; Robberecht, H.; Van Dyck, K.; Van Cauwenbergh, R.; Deelstra, H. In vitro availability of calcium, iron and zinc from first-age infant formulae and human milk. Journal of Pediatric Gastroenterology and Nutrition 2001, 32, 54-58.

19. Bosscher, D.; Lu, Z.; Janssens, G.; Van Caillie-Bertrand, M.;, Robberecht, H.; De Rycke, H.; De Wilde, R.; Deelstra, H. In vitro bioavailability of zinc from infant foods with increasing phytic acid contents. British Journal of Nutrition 2001, 86, 241-247.

20. Bosscher, D.; Van Caillie-Bertrand, M.; Deelstra, H. Effect of thickening agents, based on soluble dietary fiber, on the availability of calcium iron, and zinc from infant formulas. Nutrition 2001, 17, 614-618.

21. Van Dyck, K.; Robberecht, H.; Van Cauwenbergh, R.; Deelstra, H.; Arnaud, J.; Willemyns, L.; Benijts, F.; Centeno, J.A.; Taylor, H.; Soares, M.E.; Bastos, M.L.; Ferreira, M.A.; D’Haese, P.C.; Lamberts, L.V.; Hoenig, M.; Knapp, G.; Lugowski, S.J.; Moens, L.; Riondato, J.; Van Grieken, R.; Claes, M.; Verheyen, R.; Clement, L., Uytterhoeven, M. Spectrometric determination of silicon in food and biological samples. Journal of Analytical Atomic Spectrometry 2000, $15,735-741$.

22. Claes, M.; Van Dyck, K.; Deelstra, H.; Van Grieken, R. Determination of silicon in organic matrices with grazing-emissioin X-ray fluorescence spectrometry. Spectrochimica Acta 1999, Part B 54:1517-1524.

23. Shen, L.; Luten, J.; Robberecht, H.; Bindels, J.; Deelstra, H. Modification of an in vitro method for estimating the bioavailability of zinc and calcium from foods. Zeitschrift für LebensmittelUntersuchung und -Forschung 1994, 199, 442-445. 
24. Bellia, J.P.; Birchall, J.D.; Roberts, N.B. Beer : a dietary source of silicon. The Lancet 1994, 343, 235.

25. Reffitt, D.M.; Jugdaohsingh, R.; Thompson, R.P.H.; Powell, J.J.; Silicic acid : its gastrointestinal uptake and urinary excretion in man and effects on aluminium excretion. Journal of Inorganic Biochemistry 1999, 76, 141-146.

26. Kelsay, J.L.; Bhall, K.M.; Prathr, E.S. Effects of fiber from fruits and vegetables on metabolic responses of human subjects II. Calcium, magnesium, iron, and silicon balances. American Journal of Clinical Nutrition 1979 32, 1876-1880.

27. Carlisle, E.M. Silicon localization and calcification in developing bone. Federation Proceedings 1969, $20,374$.

28. Carlisle, E.M. Silicon: a possible factor in bone calcification. Science 1970, 167, 79-80.

29. Carlisle, E.M. Biochemical and morphological changes associated with long bone abnormalities in silicon deficiency. Journal of Nutrition 1980, 110, 352-359.

30. Koivistoinen, P. Mineral element composition of Finnish foods : N, K, Ca, Mg, P, S, Fe, Cu, $\mathrm{Mn}, \mathrm{Zn}, \mathrm{Mo}, \mathrm{Co}, \mathrm{Ni}, \mathrm{Cr}, \mathrm{F}, \mathrm{Se}, \mathrm{Si} \mathrm{Rb}, \mathrm{Al}, \mathrm{B}, \mathrm{Br}, \mathrm{Hg}, \mathrm{As}, \mathrm{Cd}, \mathrm{Pb}$ and ash. Acta Agriculturae Scandinavia 1980, Suppl 22, 1-171.

31. Nielsen, F.H. The ultratrace elements. In Trace minerals in foods; Smith, K.T. Ed., Marcel Dekker, New York, 1988; 357-425.

32. Nielsen, F.H. Other trace elements. In Present knowledge in nutrition; Brown, M.L., Ed.; International Life Sciences Institute: Washington, DC, 1990; 294-307.

33. Chen, F.; Cole, P.; Wen, L.; Mi, Z.; Trapido, E.J. Estimates of trace element intakes in Chinese farmers. Journal of Nutrition 1994, 124, 196-201.

34. Anasuya, A.; Bapurao, S.; Paranjape, P.K. Fluoride and silicon intake in normal and endemic fluorotic areas. Journal of Trace Elements in Medicine and Biology 1996, 10, 149-155.

35. Solomons, N.W. The other trace minerals : manganese, molybdenum, vanadium, nickel, silicon and arsenic. In Current topics in nutrition and disease, Vol 12. Absorption and malabsorption of mineral nutrients; Solomons, N.W., Rosenbergh, T.H., Eds.; Alan R Liss Inc., New York, 1984, 269-295. 